\title{
Anti-CNS antibodies in neurological and psychiatric disorders
}

\author{
AUDRIUS V PLIOPLYS, ${ }^{*}$ JACQUES THIBAULT, $\dagger$ JEAN-PIERRE BOUCHARD, $\ddagger$ \\ CAROL COCKBURN,* RICHARD HAWKES*
}

From the Laboratory of Neurobiology and Department of Biochemistry, Laval University,* Department of Pathology, Robert Giffard Hospital, $\dagger$ Department of Neurological Sciences, Hôpital de l'Enfant-Jésus, $\ddagger$ Quebec, Canada

SUMMARY To investigate the possibility that anti-CNS antibodies may play a pathogenic role in a number of neurological and psychiatric disorders, a population study was undertaken. Serum samples were obtained from a total of 257 adults and were screened against sodium dodecyl sulphate polyacrylamide gel electrophoretic blots of various normal, necropsy-derived adult human brain regions. The incidence of IgG immunoreactive banding in the total sample was $30 \%$. Within the diagnostic groups the incidence of banding was: controls $32 \%$, schizophrenia $28 \%$, mental retardation $27 \%$, cerebellar ataxia $33 \%$, Parkinson's disease $22 \%$, myasthenia gravis $45 \%$ and epilepsy $31 \%$. The differences are not statistically significant. There was no significant difference in the numbers and locations of bands between the various diagnostic groups and the controls. The overall incidence of immunoreactivity corresponding to the high molecular weight subunit of neurofilaments was only $6 \%$, thus not confirming a previously reported incidence of $95 \%$. The similarity between the diagnostic and the control sera suggests that caution should be exerted in interpreting the pathogenic significance of anti-CNS immunoreactive banding on Western blots.

Autoimmune involvement has been demonstrated in neurological illnesses such as myasthenia gravis, ${ }^{2-4}$ the Guillain-Barré syndrome $\mathrm{s}^{5-7}$ and multiple sclerosis (reviewed by Weiner and Hauser ${ }^{8}$ ). To investigate the possibility that anti-central nervous system (CNS) antibodies may play a wider pathogenic role in neurological and psychiatric diseases, a population study was undertaken. Serum samples were collected and screened against Western blots of human CNS tissue. Immunoblots have the advantage over tissue sections in that immunoreactivity can be resolved to a finite number of bands whose molecular weights can be determined. Our results are presented in tabular form so that comparisons with other studies will be possible.

Diagnostic groups in which the published literature suggested the presence of anti-CNS antibodies were selected for investigation: myasthenia gravis, cerebellar degenerations, diseases of the basal ganglia and

Address for reprint requests: Dr A V Plioplys, Surrey Place Centre, 2 Surrey Place, Toronto, Ontario, Canada M5S 2C2.

Received 18 July 1986 and in revised form 31 December 1986. Accepted 5 January 1987 schizophrenia. In myasthenia gravis, the serum anti body response is to the acetylocholine receptor (AChR). ${ }^{2-4}$ The possibility of anti-CNS antibody activity in myasthenia gravis has been raised in several studies. Kott and Rule $^{9}$ reported a cellular immune response to myelin basic protein in some myasthenia gravis patients. Antibodies to the AChR have been found in the cerebrospinal fluid (CSF) of some myasthenia gravis patients, suggestive of intrathecal production ${ }^{10}$ and CSF oligoclonal immunoglobulin $\mathrm{G}$ (IgG) bands have been demonstrated. ${ }^{11}$ Also, sera of myasthenia gravis patients contains significantly elevated levels of antibodies to neuroblastoma cells. ${ }^{12}$ These studies suggest a more generalised neuroimmunological abnormality in myasthenia gravis, not one limited to the neuromuscular junction.

Several lines of investigation have suggested the presence of autoantibodies in cerebellar diseases. Serum and CSF antibodies to cerebellar Purkinje cells have been demonstrated in patients with paraneoplastic cerebellar degenerations. ${ }^{13-15}$ In the childhood opsoclonus-myoclonus syndrome, circulating antibodies to Purkinje cells are present. ${ }^{16}$ Anticerebellar antibody activity in other forms of 
cerebellar degeneration has not been extensively studied. Recently, in four cases of familial spinocerebellar degeneration, serum antibodies were detected against cortical neurons, Purkinje cells and dorsal root ganglia. ${ }^{17}$

In diseases of the basal ganglia, by using immunohistochemical techniques serum antibodies to the caudate nucleus have been demonstrated in Huntington's chorea, Sydenham's chorea ${ }^{1819}$ and Parkinson's disease. ${ }^{20}$ Further studies have shown the presence of circulating antibodies to sympathetic ganglion cells in Parkinson's disease patients ${ }^{2122}$ suggestive of an autoimmune process.

Since Fessel ${ }^{23}$ postulated an autoimmune basis for schizophrenia, many studies using various immunohistochemical, radioimmunofixation and cytotoxicity techniques have been reported. Although the results are conflicting, there is reason to suspect that antiCNS antibodies may be present in a subset of schizophrenic patients (reviewed by Knight ${ }^{24}$ and DeLisi et $\mathrm{al}^{25}$ ).

In the course of collecting serum samples, a number of individuals with mental retardation, epilepsy and other neurological disorders were included. For this study it was necessary to investigate an adequate number of serum samples from healthy individuals since anti-CNS antibody activity is not limited to neurological diseases. ${ }^{1426}$

\section{Material and methods}

Serum samples were obtained from a total of 257 adults (126 females and 131 males) and stored at $-40^{\circ} \mathrm{C}$ until being used. The majority of samples were collected when routine blood tests were being performed. In all other cases informed consent was obtained. This study was approved by hospital ethics review committees.

The schizophrenia group consisted of chronic schizophrenic patients custodially hospitalised. All were taking neuroleptics. The mentally retarded group consisted of patients custodially hospitalised none of whom had a specific neurological diagnosis. The cerebellar ataxia group consisted of patients with various forms of inherited spinocerebellar degeneration: eight with Friedreich's ataxia, eight with spastic ataxia and two with other forms of ataxia. In both Parkinson's disease and myasthenia gravis categories the patients had long standing illnesses and were being treated with appropriate medications. The epileptic group consisted primarily of patients with other neurological and psychiatric disorders who also had active epilepsy requiring anticonvulsant medication. This included three schizophrenic patients, seven mentally retarded patients and one with Alzheimer's disease. In the study there were also two patients each with personality disorder and dementia of unknown aetiology, and one patient each with depression, drug abuse, Alzheimer's disease, post-traumatic encephalopathy, dystonia musculorum deformans and spasmodic torticollis. The control group consisted of healthy hospital employees undergoing routine hepatitis screening and blood donors. The number of individuals in each diagnostic group are listed in table 1.

Brain samples were obtained at the time of necropsy from three neurologically normal adults who had died from nonneurological causes. The time of necropsy was no later than 24 hours after death. Permission for the necropsy was given by the closest relative. Routine neuropathological examination was normal. The brain samples were stored at $-80^{\circ} \mathrm{C}$ until being used.

Western blots were made by standard techniques. ${ }^{27}$ Total homogenates of adult human frontal cortex, basal ganglia (equal volumes of putamen and caudate) and cerebellum were homogenised and boiled for $2 \mathrm{~min}$ in $2.5 \%$ sodium dodecyl sulphate (SDS; w/v), 7\% 2-mercaptoethanol (v/v) in TBS (50 mM Tris- $\mathrm{HCl}, 200 \mathrm{mM} \mathrm{NaCl}, \mathrm{pH} \mathrm{7.4)}$ and the proteins separated as a curtain by polyacrylamide gel electrophoresis (PAGE) through a 5 to $17 \%$ acrylamide gradient. The gel loading was $10 \mu \mathrm{g}$ protein $/ \mathrm{mm}$ track width. The separated polypeptides were electrophoretically transferred to a cellulose nitrate sheet. To detect specific antibody binding $3 \mathrm{~mm}$ wide strips from the blot were first incubated $30 \mathrm{~min}$ in $10 \%$ normal horse serum (NHS) in phosphate buffered saline (PBS; $0.1 \mathrm{M}$ phosphate buffer, $0.15 \mathrm{M} \mathrm{NaCl}, \mathrm{pH} 7.4$ ) to block non-specific binding sites, then overnight in the serum sample diluted $1: 100$ in $10 \%$ NHS. A serum concentration of 1:100 gave optimal visualisation of immunoreactive bands without significant background staining. After two $15 \mathrm{~min}$ washes in PBS, the blot strips were incubated for $2 \mathrm{~h}$ in horseradish peroxidase conjugated rabbit anti-human IgG (Dako Inc) diluted 1:100 in 10\% NHS. Antibody binding was detected by washing the blot twice for $15 \mathrm{~min}$ in PBS and then for $15 \mathrm{~min}$ in $0.5 \mathrm{mg} / \mathrm{ml}$ 4-chloro-1-naphthol-0.01\% (v/v) hydrogen peroxide. ${ }^{28}$ The apparent molecular weights of antigenic polypeptide bands in kdaltons $(\mathbf{K})$ were estimated from pre-stained molecular weight standards (BRL Inc) which were blotted concomitantly. Control blots in which the serum sample was replaced by $10 \%$ NHS revealed no bands. MabN210 is a murine monoclonal antibody which recognises the $210 \mathrm{~K}$ subunit of neurofilaments. ${ }^{29}$ Control blots in which MabN210 was substituted for the serum, and the second antibody replaced by horseradish peroxidase conjugated rabbit anti-mouse immunoglobulin (Dako Inc) diluted 1:100

Table 1 The number of studied inviduals and the incidence of serum immunoreactive banding against SDS-PAGE blots of adult brain in each diagnostic category

\begin{tabular}{lcc}
\hline Studied population & No & $\begin{array}{l}\text { Incidence } \\
\text { of banding }\end{array}$ \\
\hline Controls & 99 & $32 \%$ \\
Schizophrenia & 68 & $28 \%$ \\
Mental retardation & 22 & $27 \%$ \\
Cerebellar ataxia & 18 & $33 \%$ \\
Parkinson's disease & 18 & $22 \%$ \\
Myasthenia gravis & 20 & $45 \%$ \\
Epilepsy* & 13 & $31 \%$ \\
Other diagnoses & 10 & $10 \%$ \\
Total & 257 & $30 \%$ \\
\hline
\end{tabular}

The epilepsy category, marked by an asterisk, consists of 13 individuals with epilepsy 11 of whom are included in other neuropsychiatric diagnostic groups. 
in $10 \%$ NHS, consistently revealed an immunoreactive band at $210 \mathrm{~K}$.

Serum samples from the patients with cerebellar ataxia were screened against blots of cerebellum, those with Parkinson's disease against blots of basal ganglia, and all others, including controls and schizophrenics, against blots of frontal cortex. A number of immunoreactive sera were cross checked against all three blots and were found to give similar results. No brain region-specific immunoreactivity was identified.

All serum samples were tested at least twice on different blots to calculate the incidence of banding in table 1 and tabulate the identified molecular weights in table 2 .

For statistical analysis, chi-square and the Fisher exact probability tests were used.

\section{Results}

When tested against Western blots prepared with human frontal cortex, 67 serum samples from the control group of 99 individuals displayed no banding. Of the 32 that did react, 21 had only one reactive band, and the others two or more. The overall incidence of positive banding was $32 \%$. A selection of strips from the same Western blot reacted with sera of the control group are illustrated in fig 1 . The apparent molecular weights of the identified CNS antigens and the intensity of staining of each individual band varied greatly between serum samples. The majority of control results were as those in strips 9 and 10 of fig 1 with no banding. The apparent molecular weights of all the CNS antigens identified by the sera of the control group are presented in table 2.

The largest single patient group studied was that of schizophrenia with 68 cases. When tested against Western blots made from human frontal cortex, $19(28 \%)$ showed immunoreactive banding. Of those that did, again the majority of 11 displayed only one band. A selection of strips from the same Western blot reacted with sera of the schizophrenic group are illustrated in fig 2. As in the control group, the identified antigen molecular weights and intensity of staining of each band varied greatly between serum samples. The majority of schizophrenic serum results were as those in strips 9 and 10 of fig 2 with no banding. The apparent molecular weights of all the CNS antigens identified by the sera of the schizophrenic group are presented in table 2 .

The overall incidence of immunoreactive banding in each of the diagnostic groups is presented in table 1. The identified CNS antigen apparent molecular weights are summarised in table 2. For the total studied population of 257 , the incidence of banding was $30 \%$. In those that had bands $65 \%$ had only one band and $35 \%$ had multiple bands. The distribution of the number of immunoreactive bands is illustrated in fig 3.
Table 2 Molecular weights (in daltons) of identified serum immunoreactive bands against SDS-PAGE blots of adult human brain are listed for each diagnostic group

$\begin{array}{ll}\text { Controls } & \text { Schizophrenics } \\ 26,55,61,167 & 58,64,120 \\ 210 & 114,167 \\ 160 & 14,19 \\ 18,131 & 19,97 \\ 19,167,210 & 157,210 \\ 19 & 172,210 \\ 16,19,49 & 19 \\ 26,40,56,63,143,168 & 19,60,64,101,114 \text { to } 130, \\ 140 & 135,172,210 \\ 24 & 210 \\ 68,80 & 40 \\ 125 & 210 \\ 61,67 & 24 \\ 39 & 26 \\ 120 & 185 \\ 12 & 68,80 \\ 17,210 & 170 \\ 23 & 70 \\ 28 & 210 \\ 50,64 & 26 \\ 210 & \text { No bands in } 49 \text { cases } \\ 28 & \\ 210 & \text { Mental retardation } \\ 32,40 & 41 \\ 36,180 & 23,25 \\ 35 & 165 \\ 15 & 27 \\ 210 & 126 \\ 170 & 52 \\ 210 & \text { No bands in } 16 \text { cases } \\ 35 & \\ 167 & \text { Epilepsy* } \\ \text { No bands in } 67 \text { cases } & 20 \\ \text { Parkinson's disease } & 170 \\ 26,72,80 & 27 \\ 17 & 52 \\ 14 & \text { No bands in nine cases } \\ 180 & \\ \text { No bands in } 14 \text { cases } & \text { Myasthenia gravis } \\ \text { Cerebellar ataxia } & 23,25,27,130 \\ 19,50 & 110 \\ 19,210 & 30,100 \\ 23,30 & 22 \\ 17 & 39 \\ 30,50,210 & 150 \\ 210 & 23 \\ \text { No bands in } 12 \text { cases } & 19 \\ & 100,150 \\ \text { No bands in } 11 \text { cases } \\ \\ 10\end{array}$

Others diagnoses

185

No bands in nine cases

The epilepsy category consists of 13 individuals with epilepsy 11 of whom are included in other neuropsychiatric diagnostic groups. Of the two cases with epilepsy not included in other diagnostic groups, one had a reactive band at $20 \mathrm{~K}$ and the other had no band. The immunoblots of the first eight entries in the normal control and schizophrenic categories are illustrated in figs 1 and 2 respectively.

There was no statistically significant difference in the incidence of banding when the diagnostic groups were compared to each other, to the controls, or to the entire studied population. There was also no statistically significant difference in the incidence of multiple bands when the diagnostic groups were 


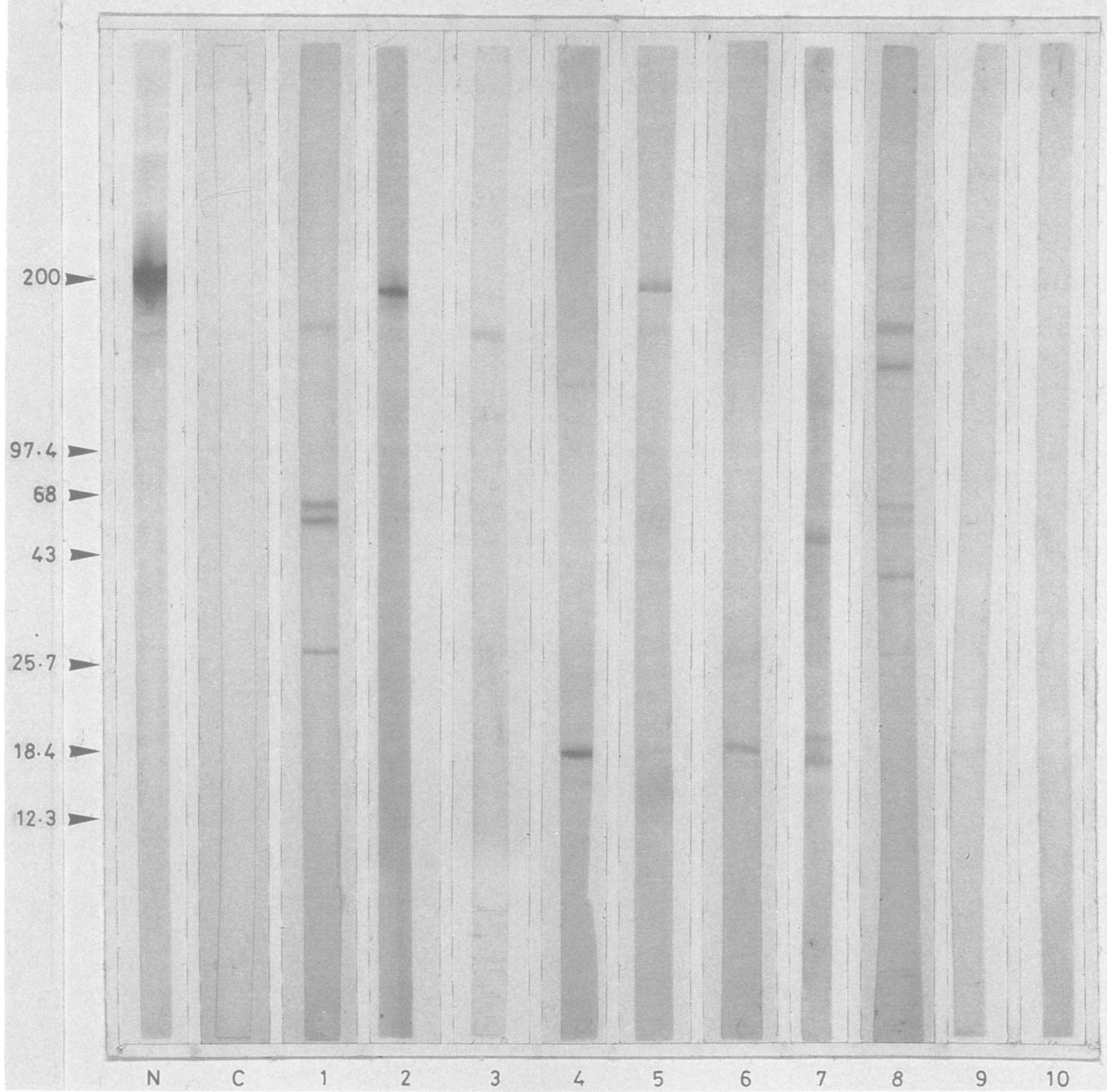

Fig 1 A sample of strips, taken from the same Western blot of adult human frontal cortex, illustrating serum immunoreactive banding in the controls. The protein standard molecular weights in daltons are shown on the left. $N$ is a positive control reacted with mabN210 which recognises the 210 dalton subunit of neurofilaments. C is a negative control in which the serum sample was omitted from the primary incubation. The molecular weights of the immunoreactive bands from cases 1 to 8 are listed as the first eight entries in the controls column of table 2. Cases 9 and 10 display no banding.

compared with each other, with the controls or with the entire studied population. When the immunoreactive bands were separated into categories by molecular weight (high: greater than $90 \mathrm{~K}$; middle: $40 \mathrm{~K}$ to $90 \mathrm{~K}$; low: less than $40 \mathrm{~K}$ ) and the comparative analyses repeated, there again was no statistically significant difference between each diagnostic group, the controls and the entire studied population. There was no single band or set of bands that was characteristic of any diagnostic group.
An increase with age in the proportion of antibodies against the CNS in man has been reported by Ingram et al. ${ }^{30}$ Using immunohistochemical techniques, he noted a sharp rise in the incidence of antiCNS antibodies after the age of 55 years. The incidence of anti-neurofilament serum reactivity has likewise been reported to increase with advancing age, particularly so in those over $70 .{ }^{26}$ We did not observe a significant difference in the incidence of banding with advancing age within any studied category. For 


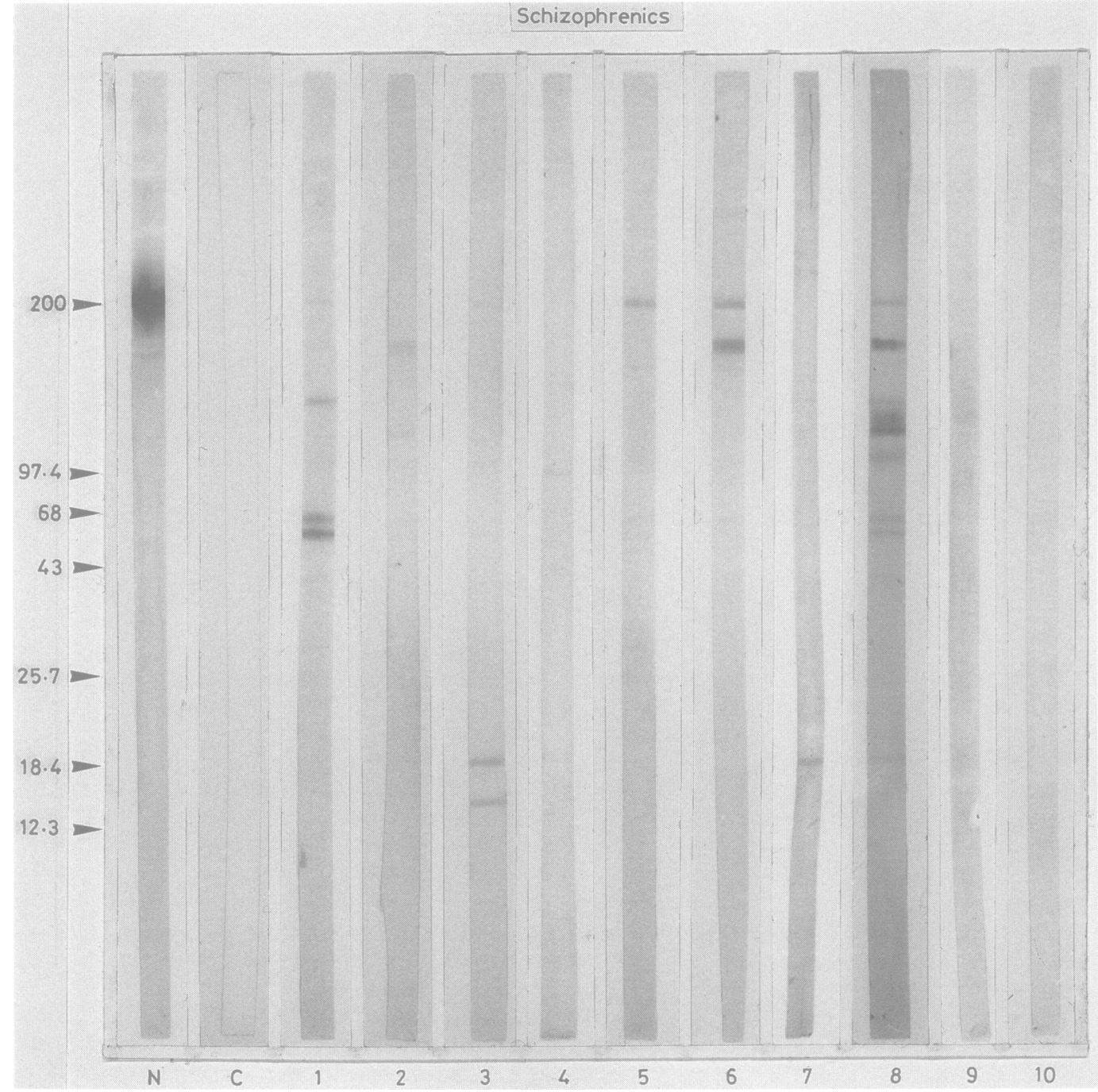

Fig 2 A sample of strips, taken from the same Western blot of adult human frontal cortex, illustrating serum immunoreactive banding in schizophrenic patients. The protein standard molecular weights in daltons are shown on the left. $N$ is a positive control reacted with mabN210 which recognises the 210 dalton subunit of neurofilaments. $C$ is a negative control in which the serum sample was omitted from the primary incubation. The molecular weights of the immunoreactive bands from cases 1 to 8 are listed as the first eight entries in the schizophrenic column of table 2 . Cases 9 and 10 display no banding.

the total study group, the incidence of banding in the second decade was $33 \%$, third decade $41 \%$, fourth decade $35 \%$, fifth decade $21 \%$, sixth decade $39 \%$, and those over $70,29 \%$. These results are illustrated as a bar graph in fig 4 . None of the differences between decades were statistically significant.

We did not notice a significant difference in the incidence of banding within any diagnostic group between males and females. For the total study group, the incidence of reactive bands in males was $34 \%$ and females $28 \%$, a difference which is not statistically significant. There was no significant difference in the incidence of banding between males and females in each decade of age.

Since medications can induce immune mediated diseases, perhaps a more significant negative finding was that of no correlation between medication intake and the incidence of banding. Everyone in the epi- 


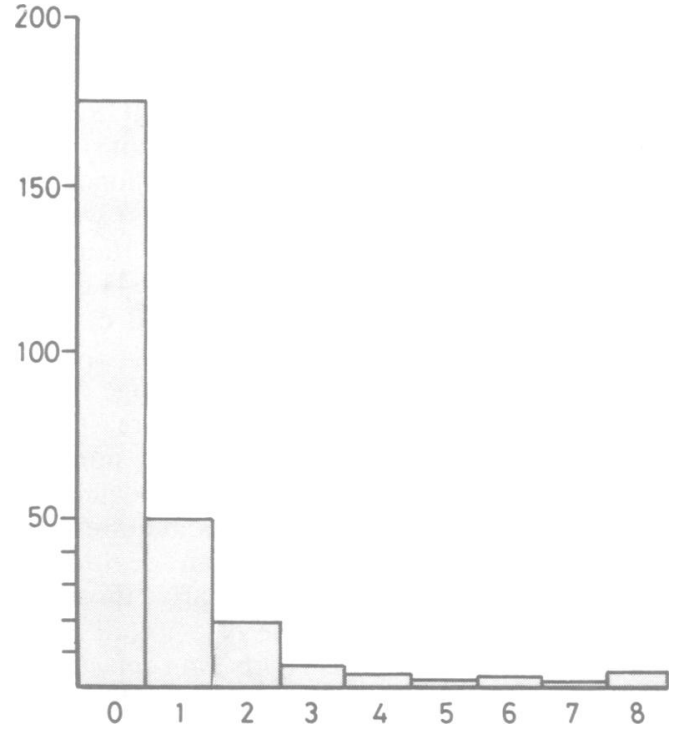

Fig 3 A histogram of the number of immunoreactive bands from each individual of the total studied population. The abscissa $(0$ to 8$)$ indicates the number of immunoreactive bands on each reacted blot. The ordinate indicates the number of studied individuals with the indicated number of bands. The majority, 179 out of a total of $257(70 \%)$ had no immunoreactive banding (column 0). Of those that had hands, $65 \%$ had only one band (column 1) and $35 \%$ had multiple bands (columns 2 through 8 ).

leptic group was taking anticonvulsants and everyone in the schizophrenic group was taking neuroleptics. Amongst the side effects of anticonvulsants there are immune mediated ones such as hypersensitivity dermatitis, lymphoma-like lesions, lupus-like manifestations, lymphotoxic autoantibodies, defects in cell-mediated immunity, thyroiditis and myasthenia gravis. ${ }^{3132}$ For the neuroleptics the immune mediated side effects include hypersensitivity dermatitis, agranulocytosis, hemolytic anaemia and thrombocytopenia. ${ }^{334}$ There was no difference in the incidence of banding between the epileptic, schizophrenic and control groups. No one in any of the diagnostic categories was known to have an immunological primary disease or one induced by medications. No one was receiving immunosuppressive medications.

In the schizophrenic group five patients had tardive dyskinesia, a presumably non-immune complication of neuroleptics. ${ }^{34}$ Of these, three had immunoreactive bands, results which did not differ significantly from the controls.

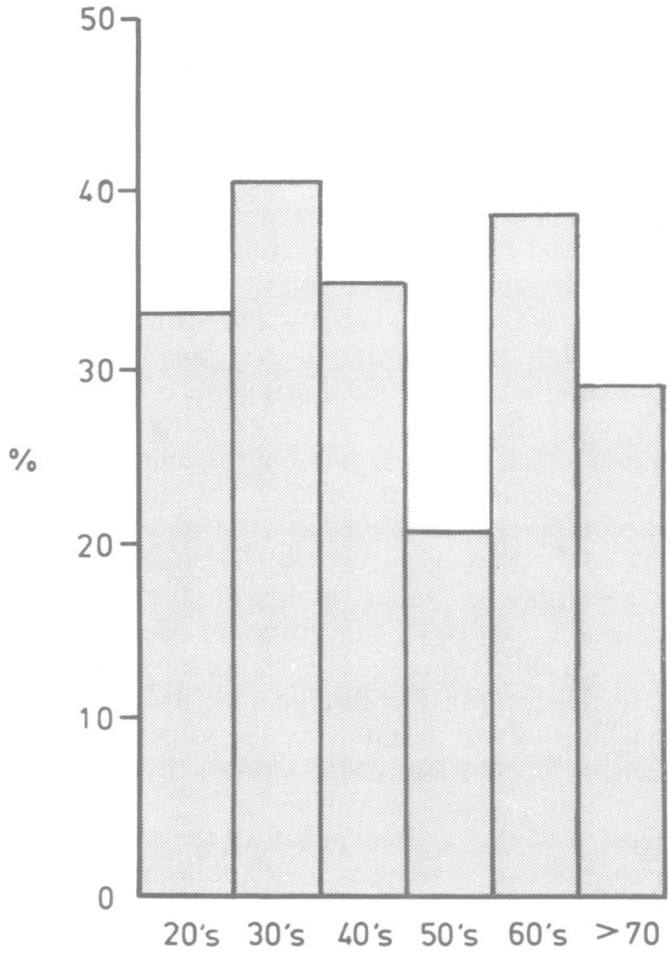

Fig 4 A histogram of the incidence of immunoreactive banding (\%) by decade of age in the total studied population. None of the differences between decades is statistically significant.

\section{Discussion}

For this study we had selected diagnostic groups in which the published literature had suggested the possibility of anti-CNS antibodies. No correlation was found between the incidence and pattern of immunoreactive banding and disease category. The normal controls were indistinguishable from the other groups. There was no single band or set of bands that was characteristic of any diagnostic category.

Overall, $70 \%$ of our studied population had no immunoreactive banding. Of those that did, $65 \%$ had only one band and the remainder two or more. We did not observe an increase in the incidence of banding with advancing age, as had been suggested in two previous reports using immunohistochemical techniques. ${ }^{26} 30$ There was no statistically significant difference in the incidence of banding between males and females. Also, there was no statistically significant difference between controls and those patient populations taking neuroleptics and anticonvulsants. 
The results presented in table 2 can be used to compare the incidence of serum immunoreactive banding at selected molecular weights with those from other series. For example, it has been claimed that circulating anti-neurofilament antibodies may play a pathogenic role in Creutzfeldt-Jakob disease, Kuru, ${ }^{35} 36$ and the opsoclonus-myoclonus syndrome of childhood. ${ }^{1637}$ Using immunoblots of human brain Stefansson et $\mathrm{al}^{1}$ reported that the incidence of anti-210K IgG serum activity in normals and in patients with neurological disease was $95 \%$. Our results for the total studied population showed an incidence of only $6 \%$, closer to the reported incidence of immunohistochemical anti-neurofilament activity of $16 \%$ in a study group of $249 .{ }^{26}$ The reason for the marked difference between our results and that of Stefansson et al ${ }^{1}$ is not clear. Possibly, differences in the techniques of tissue homogenisation and gel preparation, as well as concentration of serum used (we used a dilution of 1:100, Stefansson used 1:50), might account for the discrepancy. However, the implication of our results was the same as that of Stefansson in that anti-210K serum activity did not correlate with diagnostic categories.

There was also a discrepancy in the incidence of immunoreactive banding at lower molecular weights between our results and those of Stefansson et al. ${ }^{1}$ Combining the results of the normal controls and the neurological patients, Stefansson reported that $14 \%$ of his study group had bands at molecular weights other than $210 \mathrm{~K}$. Our results are that 69 of the 257 , or $27 \%$, had such reactivity. This difference is statistically significant with $\mathrm{p}<0.05$. Again, methodological considerations may account for the observed differences.

The results in table 2 can be compared with other published reports of serum immunoreactivity. In paraneoplastic cerebellar degeneration, one reported claimed that a $85 \mathrm{~K}$ polypeptide is identified by the sera of affected individuals ${ }^{38}$ and a second one that multiple antigenic determinants with molecular weights of $34 \mathrm{~K}$ to $38 \mathrm{~K}$ and $62 \mathrm{~K}$ to $64 \mathrm{~K}$ are recognised. ${ }^{39}$ Looking at immunoreactive banding between the molecular weights of $34 \mathrm{~K}$ and $38 \mathrm{~K}$, table 2 shows three cases out of a total of 257 for an incidence of $1 \%$; between $62 \mathrm{~K}$ and $64 \mathrm{~K}$, four cases, or $2 \%$; and between $80 \mathrm{~K}$ and $90 \mathrm{~K}$ three cases, or $1 \%$. Thus banding at these molecular weights does occur, but uncommonly. It has been claimed that in Devic's syndrome there are CSF and serum antibodies to glial fibrillary acidic protein (GFAP) ${ }^{40}$ Human GFAP polypeptides have molecular weights between $39 \mathrm{~K}$ and $49 \mathrm{~K} .{ }^{41-43}$ Reviewing the data in table 2 , the incidence of banding between these two molecular weights was seven out of 257 , or $3 \%$. In the case of polyneuropathy with monoclonal gammapathy, my- elin associated glycoprotein of a molecular weight $110 \mathrm{~K}$ is being recognised. ${ }^{4-46}$ Between molecular weights $100 \mathrm{~K}$ and $120 \mathrm{~K}$, the incidence of banding in our study was seven out of 257 , or $3 \%$. It is controversial whether circulating antibodies against myelin basic protein (MBP) play a role in the pathogenesis of multiple sclerosis. ${ }^{4-49}$ With the molecular weight of MBP being $18.5 \mathrm{~K}^{5051}$ the studied population had a banding incidence of 11 out of 257 , or $4 \%$, in the range $18 \mathrm{~K}$ to $19 \mathrm{~K}$. None of the studied cases was known to have multiple sclerosis.

As has been demonstrated, an advantage of using Western blots to study serum immunoreactivity is that the results can be resolved to a finite number of bands whose molecular weights can be determined. However, the preparation of blots requires tissuc homogenation in solvents that can degrade and denature neural antigens particularly those with lipid components. It is probable that not all positive serum anti-CNS immunoreactivity was detected.

The similarity in reactivity between the various diagnostic groups and the normal controls suggests that caution must be exerted in interpreting the pathogenic significance of anti-CNS immunoreactive banding on Western blots.

We thank Dr Paul Bédard and the Croix-Rouge for assistance in collecting serum samples, and the medical records section of the Robert Giffard Hospital for abstracting the clinical information. This work was supported by grants from the Medical Research Council of Canada and Fonds de la Paralysic Cérébrale, and by a MRC fellowship to AVP.

\section{References}

1 Stefansson K, Morton LS, Dieperink ME, Molnar GK, Schlaepfer WW, Helgason CM. Circulating autoantibodies to the 200,000-Dalton protein of neurofilaments in the serum of healthy individuals. Science 1985;228:1117-9

2 Patrick J, Lindstrom J. Autoimmune response to acetyl-choline receptor. Science 1973;180:871-2.

3 Appel SH, Almon RR, Levy N. Acetylcholine receptor antibodies in myasthenia gravis. $N$ Engl J Med 1975;293:760-1.

4 Toyka KV, Drachman DB, Griffin DE, et al. Myasthenia gravis - study of humoral immune mechanisms by passive transfer to mice. $N$ Engl J Med 1977;296:125-31.

5 Tse KS, Arbesman CE, Tomasi TB. Demonstration of antimyelin antibodies by immunofluorescence in Guillain-Barre syndrome. Clin Exp Immunol 1971;8:881-7.

6 Nyland H, Aarli JA. Guillain-Barré syndrome: demonstration of antibodies to peripheral nerve tissue. Acta Neurol Scand 1978;58:35-43.

7 Ryberg B, Hindfelt B, Nilsson B, Olsson JE. Antineural antibodies in Guillain-Barré syndrome and lymphocytic meningoradiculitis (Bannwarth's syndrome). Arch Neurol 1984; 41: $1277-81$

8 Weiner HL, Hauser SL. Neuroimmunology I: immunoregulation in neurological disease. Ann Neurol 1982;11: 
437-49.

9 Kott E, Rule AH. Myasthenia gravis-cellular response to basic myelin protein compared with cellular and humoral immunity to muscle antigens. Neurology 1973;23:745-8.

10 Lefvert AK, Pirskanen R. Acetylcholine-receptor antibodies in cerebrospinal fluid of patients with myasthenia gravis. Lancet 1977;II:351-2.

11 Müller K. Taskinen E, Keski-Oja J, Kovanen J, Pirskanen R, Iivanainen $\mathbf{M}$. Oligoclonal IgG and lymphoid cell reaction in the CSF of patients with myasthenia gravis. Acta Neurol Scand 1982;65 (Suppl 90): 144-5.

12 Müller KMI, Anderson LC. Antibodies against human neuroblastoma cells in the sera of patients with myasthenia gravis. $J$ Neuroimmunol 1984;7:97-105.

13 Trotter JL, Hendin BA, Osterland K. Cerebellar degeneration with Hodgkin disease: an immunological study. Arch Neurol 1976;33:660-1.

14 Greenlee JE, Brashear HR. Antibodies to cerebellar Purkinje cells in patients with paraneoplastic degeneration and ovarian carcinoma. Ann Neurol 1983;14:609-13.

15 Jaeckle KA, Graus F, Houghtan A, Cardon-Cardo C, Nielsen SL, Posner JB. Autoimmune response of patients with paraneoplastic cerebellar degeneration to a Purkinje cell cytoplasmic protein antigen. Ann Neurol 1985;18:592-600.

16 Cawley LP, James VL, Minard BJ, Bryant SA. Antibodies to Purkinje cells and peripheral nerve in opoclonia. Lancet 1984;I:509-10

17 Liwnicz BH, Dhib-Jalbut S. Immunocytochemical binding to human neurons and complement-dependent cytotoxicity of serum from patients with spino-cerebellar degeneration. Neurology 1985;35 (Suppl 1): 168.

18 Husby G, Van de Rijn I, Zabriskie JB, Abdin ZH, Williams RC Jr. Antibodies reacting with cytoplasm of subthalamic and caudate nuclei neurons in chorea and acute rheumatic fever. $J$ Exp Med 1976;1441:1094-110.

19 Husby G, Li L, David LE, Wedege E, Kokmen E, Williams RC Jr. Antibodies to human caudate nucleus neurons in Huntington's chorea. J Clin Invest 1977;59:922-32.

20 Husby G, Williams RC, Bersin RM, Lewis MK. In: Rose FC, ed. Clinical Neuroimmunology, Oxford: Blackwell, 1979:99-105.

21 Pouplard A, Emle J, Pouplard F, Hurez D. Parkinsonism and autoimmunity: antibody against human sympathetic ganglion cells in Parkinson's disease. Adv Neurol 1979;24:321-6.

22 Emile J, Pouplard A, Bossu van Nieuwenhuyse C, Bernat-Viallet $\mathrm{CH}$. Maladie de Parkinson, dysautonomie et auto-anticorps dirigés contre les neurons sympathiques. Rev Neurol (Paris) 1980;136:221-33

23 Fessel WJ. Blood proteins in functional psychoses. A review of the literature and unifying hypothesis. Arch Gen Psychiatry 1962;6:132-48

$24 \mathrm{Knight}$ JG. Is schizophrenia an autoimmune disease?--A review. Methods Find Exptl Clin Pharmacol 1984;6:395-403.

25 DeLisi LE, Weber RJ, Pert CB. Are there antibodies against brain in sera from schizophrenic patients? Review and prospectus. Biol Psychiatry 1985;20:94-119.

26 Elizan TS, Casals J, Yahr MD. Antineurofilament antibodies in postencephalitic and idiopathic Parkinson's disease. J Neurol Sci 1983;59:341-7.

27 Towbin H, Staehelin T, Gordon J. A procedure for the electrophoretic transfer of proteins from polyacrylamide gels to nitrocellulose sheets and some applications. Proc Nat Acad Sci (USA) 1979:76:4350-4

28 Hawkes R. Niday E, Gordon J. A dot immunobinding assay for monoclonal and other antibodies. Anal Biochem 1982:119:142-7.

29 Leclerc N, Gravel C, Plioplys A, Hawkes R. Basket cell development in the normal and hypothyroid rate cerebellar cortex studied with a monoclonal anti-neurofilament antibody. Can $J$
Biochem Biol 1985;63:564-76

30 Ingram CR, Phegan KJ, Blumenthal HT. Significance of an aging-linked neuron-binding gamma globulin fraction of human serum. J Gerontol 1974;29:20-27.

31 Booker HE. Idiosyncratic reactions to the antiepileptic drugs. Epilepsia 1975;16:171-81.

32 Dosch HM Jason J, Gelfand EW. Transient antibody deficiency and abnormal T-suppressor cells induced by phenytoin. New Engl J Med 1982;306:406-9.

33 Davis JM, Cole JO. Antipsychotic drugs. In: Freedman DX, Dyrud JE, eds. American Handbook of Psychiatry. Vol V. 2nd ed. New York: Basic Books, 1975:463-5.

34 Black JL, Richelson E, Richardson JW. Antipsychotic agents: a clinical update. Mayo Clin Proc 1985;60:777-89.

35 Sotelo J, Gibbs CJ Jr, Gajdusek DC. Autoantibodies against axonal neurofilaments in patients with Kuru and CreutzfeldJakob disease. Science 1980;210:190-3.

36 Bahmanyar S, Liem RKH, Griffin JW, Gajdusek DC. Characterization of antineurofilament autoantibodies in CreutzfeldtJakob disease. J Neuropathol Expt Neurol 1984;43:369-75.

37 Noetzel MJ, Cawley LP, James VL, Minard BJ. Antineurofilament protein antibodies in a child with opsoclonusmyoclonus. Ann Neurol 1985;18:403.

38 Brown RH Jr, Ronthal M, Come S, et al. Antibodies to 85,000 dalton protein in paracarcinomatous cerebellar degeneration Neurology 1985;35 (Supp 1):288.

39 Cunningham JM, Graus F, Anderson N, Posner JB. Partial characterization of the antigens in paraneoplastic cerebral degeneration. Neurology 1986;36 (Supp 1):331

40 Chou CH, Chou FCH, Tourtellotte WW, Kibler RF. Devic's syndrome: antibody to glial fibrillary acidic protein in cerebrospinal fluid. Neurology 1984;34:86-88.

41 Dahl D, Bignami A. Glial fibrillary acidic protein from normal and gliosed human brain: demonstration of multiple related polypeptides. Biochem Biophys Acta 1975;385:41-51.

42 Goldman JE, Schaumburg HE, Norton WT. Isolation and characterization of glial filaments from human brain. $J$ Cell Biol 1978;78:426-40.

43 Chiu FC, Korey B, Norton WT. Intermediate filaments from bovine, rat and human central nervous system: mapping analysis of the major proteins. $J$ Neurochem 1980;34:1149-59.

44 Latov N, Sherman WH, Nemni R, et al. Plasma cell dyscrasia and peripheral neuropathy with a monoclonal antibody to peripheral nerve myelin. $N$ Engl J Med 1980;303:618-21.

45 Braun PE, Latov N, Frail DE. Myelin associated glycoprotein is the antigen for a monoclonal IgM in polyneuropathy. $J$ Neurochem 1982;39:1261-5.

46 Mendell JR, Sahenk Z, Whitaker JN, et al. Polyneuropathy and IgM monoclonal gammopathy: studies on the pathogenetic role of anti-myelin-associated glycoprotein antibody. Ann Neurol 1985;17:243-54.

47 Sheremata W, Wood DD, Moscarello AA, Cosgrove JBR. Sensitization to myelin basic protein in attacks of multiple sclerosis J Neurol Sci 1978;36:165-70.

48 Jen Chou $\mathrm{CH}$, Tourtellotte WW, Kibler RF. Failure to detect antibodies to myelin basic protein or peptide fragments of myelin basic protein in CSF of patients with multiple sclerosis. Neurology 1983;33:24-8.

49 Gorny MK, Wroblewska Z, Pleasure D, Miller SL, Wojgt A, Kaprowski H. CSF antibodies to myelin basic protein and oligodendrocytes in multiple sclerosis and other neurological disease. Acta Neurol Scand 1983;67:338-47.

50 Whitaker JN. Myelin encephalitogenic protein fragments in cerebrospinal fluid of persons with multiple sclerosis. Neurology 1977;27:911-20.

51 Eylar EH, Thompson M. Allergic encephalomyelitis: the physiochemical properties of the basic protein encephalitogen from bovine spinal cord. Arch Biochem Biophys 1969;129:468-79. 